\title{
The Devonian-Carboniferous boundary in South Africa and the age of the earliest episode of the Dwyka glaciation: New palynological result
}

1 University of Liège, Department of Paleontology, Bât. B18, Sart-Tilman, 4000 Liège 1, Belgium.

2 University of Stellenbosch, Department of Geology, Private Bag X1, Matieland 7602, South Africa.

\begin{abstract}
Miospores, fish fauna and probably megaflora concur to assign a Lower Carboniferous age to the Waaipoort Formation (Witteberg Group), thus supporting the suggestion that the Devonian-Carboniferous boundary in South-Africa lies at the level of the conspicuous lithological reversal represented by the Witpoort/Kweekvlei contact. All the evidence displayed indicates overriding of the Dwyka glaciers relatively shortly after deposition of the uppermost Witteberg sediments.
\end{abstract}

\section{Introduction}

Recognition of the Devonian-Carboniferous boundary in South Africa has always been problematical. In an earlier paper Theron (1994) delineated the available information and discussed all the major aspects involved. The importance of this boundary for regional mapping purposes was stressed as well as the fact that it would give a reliable age for the advent of the earliest glacial episodes of the late Palaeozoic Dwyka Group in South Africa. These latter deposits rest unconformably on a glacigene surface which is constituted of the uppermost Cape Supergroup (Witteberg Group) south of latitude $32^{\circ} 50^{\prime}$ 'S (Figure 1). The duration of this hiatus between the Witteberg and Dwyka beds has always been problemat-

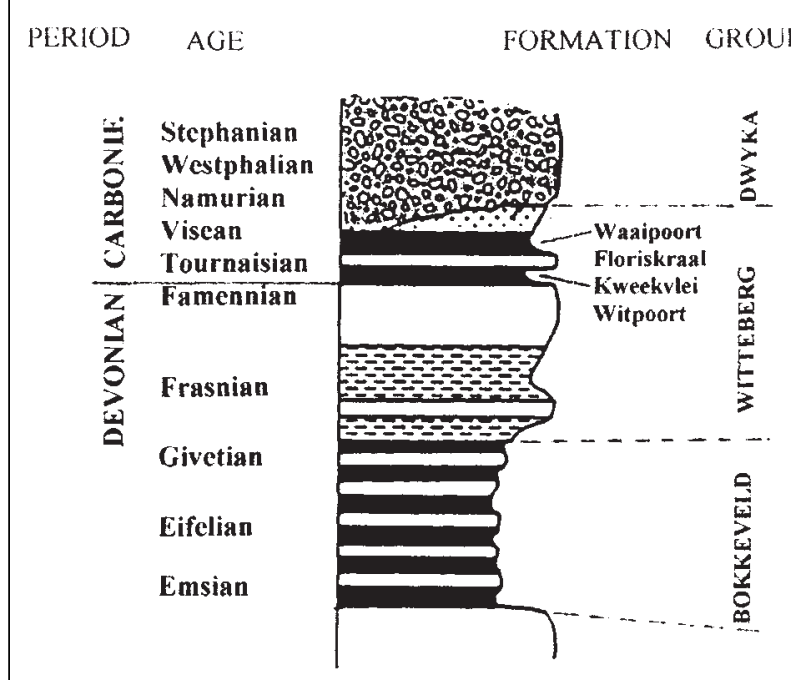

Figure 1 Generalized stratigraphical column. ical and the variable and often contradictory fossil evidence from these units adds to the confusion.

The indisputable Devonian age for the underlying Bokkeveld Group as well as the major portion of the Witteberg Group, is evident from their fossil faunal content (Boucot et al., 1983 ; Hiller and Theron, 1988; Theron and Johnson, 1991). Additionally, the plant genus Archaeopteris from the upper part of the Witpoort Formation in the Eastern Cape at Grahamstown (130 km northeast of Port Elizabeth) supports a late Devonian age (Taylor and Hiller, 1992; Anderson et al., 1995). These rocks have also been dated as Late Devonian (see later), on the basis of sea-level curves (Cooper, 1986), a conclusion supported also by the presence of a distinctive placoderm assemblage comprising Bothriolepis, groenlandaspids and phyllolepids (Young, 1989; Anderson et al., 1995).

The evidence with respect to the age of the uppermost portion of the Witteberg Group, the Waaipoort Formation, is contradictory however. Gardiner (1969) correlated the fish fauna (actinopterigians, chondrichthyans and acanthodians), which characterizes the Waaipoort Formation throughout its outcrop, with Lower Carboniferous (Viséan) actinopterigian Scottish families. Additionally, the conspicuous lithological replacement of the markedly arenitic whiteweathering Witpoort Formation by the overlying dark grey pelitic Kweekvlei Formation over more than $700 \mathrm{~km}$, clearly represents a major transgressive event. Application of sequence stratigraphical dating to the Devonian Bokkeveld and Witteberg sequence induced Cooper (1986) to relate the extensive quartz-shoal sedimentation of the Witpoort Formation to the prominent Famennian regression of the northern hemisphere. The Kweekvlei Formation would then reflect the following Tournaisian transgressive cycle. On the other hand, according to Plumstead (1967), the "Upper Witteberg Series" (Waaipoort Formation) contain, aside from many unidentifiable stems, the lycopod Protolepidodendron eximium Frenguelli, believed at that time, to belong to the upper part of the Middle Devonian. This age was later corroborated by Stapleton (1977a and b) on the basis of a palynological analysis from a very poorly preserved assemblage extracted from one of the fish-bearing nodules. The megaflora identified by Plumstead and the nodule studied by Stapleton were collected from the Eastern Cape near Willowmore.

In view of this uncertainty and contradictory evidence, a palynological investigation of the uppermost Witteberg units was undertaken. Increased tectonic deformation associated with the Cape Fold Belt south and eastwards suggested that the most worthwhile results for extraction of spores would be from outcrops in the southwestern Cape (Figure 2). Some samples were, however, also collected between Prince Albert and Willowmore to evaluate Stapleton's results. A total of 25 samples were macerated from the Kweekvlei and the Waaipoort Formations (Table 1). Investigation of the Kweekvlei Formation's samples has not yielded any identifiable spores owing to the high thermal maturity of the rocks (see also Theron, 1994, page 299). In the Waaipoort Formation most of the samples, which were largely obtained from fossiliferous nodules, also revealed that the thermal maturity was so high that it was impos- 


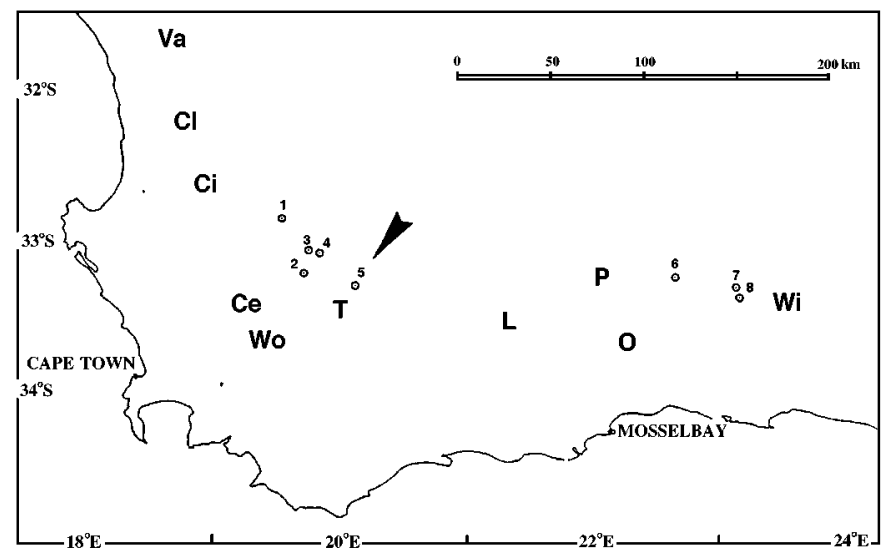

Figure 2 Localities from which samples were collected for processing. $C e=$ Ceres, $C i=$ Citrusdal, $C l=$ Clanwilliam, $L=$ Ladismith, $\boldsymbol{O}=$ Oudtshoorn, $P=$ Prince Albert, $T=$ Touws River, $V=$ Vanrhynsdorp,$W i=$ Willowmore, Wo $=$ Worcester

sible to identify most palynomorphs even when they were present. This result concurs with that of Stapleton whose data were obtained only from scanning electron microscopy (SEM) analysis. As quoted by Stapleton (1977b, page 428) very few spores have so far been illustrated by SEM and there are problems in relating SEM images to conventional transmitted light images.

However, sample $\mathrm{N}^{\circ} \mathbf{9 4 / 2}$ from Konstabel (locality 5) yielded for the first time in the Waaipoort Formation translucent material, of which the most diagnostic taxa are cited and illustrated in this preliminary paper.

\section{Miospores from the Waaipoort Formation}

All the samples were treated by the usual maceration technique with hydrochloric and hydrofluoric acids followed by sieving $(12 \mu)$ processes. Although different treatments of oxydation (dry Schulze 2 seconds to a few minutes; wet Schulze a few minutes to several days) were also applied to these samples, most of the spores remained opaque even in sample 94/2. Translucent miospores (no megaspores) were isolated only from this sample (see Plate 1).

Diagnostic taxa are listed below:

Rugospora polyptycha Neves \& Ioannides 1974 (Plate 1, Figure 10) Schopfites cf. delicatus Higgs 1988 (Plate 1, Figure 4)

Spelaeotriletes balteatus (Playford) Higgs 1975 (Plate 1, Figure 3 )

S. crustatus Higgs 1975 (Plate 1, Figure 1 ).

S. obtusus Higgs 1975 (Plate 1, Figure 2)

S. pretiosus (Playford) Neves \& Belt 1970 (Plate 1, Figure 9 )

Umbonatisporites sp. (Plate 1, Figures 5, 6 ).

Vallatisporites cf. banffensis Staplin \& Jansonius 1964 (Plate 1,

Figures 7, 8).

Table 2 Compared stratigraphical distribution of miospore and conodont zones in western Europe (based on Higgs et al., 1988, 1992). $s=$ sulcata; dupl = duplicata; sand = sandbergi; e.cren = early crenulata; l.cren = late crenulata.

\begin{tabular}{|c|c|}
\hline Systems & DEVONIAN/ C A $R$ B O $N$ I $F$ E $R$ O U $S$ \\
\hline Series & Famennian/ $\mathrm{T}$ o $u$ u $\mathbf{n}$ a $\mathrm{i}$ s i a $\mathrm{n}$ /Viséan \\
\hline Miospore zones & LL/LE/LN / VI / HD / $\mathrm{BP} / \mathrm{PC} / \mathrm{CM} / \mathrm{Pu}$ \\
\hline Conodont zones & praesulcata/s/dupl/sand/e.cren/.cren \\
\hline S. crustatus & 000000000000000000000000000000 \\
\hline S. obtusus & $000000000000000 ? ?$ \\
\hline R polyptycha & o00000000000000000000?? \\
\hline S. balteatus & 0000000000000000000 \\
\hline S.cf. delicatus & 0000000000 \\
\hline S. pretiosus & 00000000000000 \\
\hline
\end{tabular}

Table 1 Samples investigated for palynological analysis (See also Figure 2)

\begin{tabular}{ll} 
Kweekvlei Formation \\
Loc. 1 & Grasberg/Koolfontein \\
Loc. 2 & Karoopoort \\
Waaipoort Formation \\
\hline Loc. 3 & Avontuur/Bloedrivier \\
Loc. 4 & Fonteinkop \\
Loc. 5 & Konstabel \\
Loc. 6 & Swartskraal \\
Loc. 7 & Strydomsvlei \\
Loc. 8 & Soetendalsvlei
\end{tabular}

sample $89 / 1$

samples $89 / 2-6$

$\begin{array}{rl}\text { samples } & 96 / 1-6 \\ " & 96 / 7-11 \\ " & 94 / 1-2 \\ " & 94 / 3-4 \\ " & 94 / 5 \\ " & 94 / 6-8\end{array}$

The following species are well known from the Tournaisian of Ireland (Higgs et al., 1988) and Belgium (Higgs et al., 1992). Their stratigraphic ranges (see Table 2) are listed below:

$R$. polyptycha (Zones HD to CM), S. cf. delicatus (Zones PC to CM), S. balteatus (Zones BP to CM), S. crustatus (Zones LL to PC), $S$. obtusus (Zones VI to BP), S. pretiosus (Zones PC to CM).

Umbonatisporites is also a typical Tournaisian genus.

$V$. banffensis and $V$. cf. banffensis have been recorded from Tournaisian beds of North Brazil (Zones VIIIc/IX/X of Daemon 1974), North Africa (Zones L10/M2/M3 of Lanzoni \& Magloire 1969) and North-West Canada (Zone BV of Braman \& Hills 1992).

Due to the presence of $S$. cf. delicatus and S. pretiosus, the oldest age of this assemblage is late Middle Tournaisian, corresponding to the late crenulata conodont Zone (Higgs et al., 1992) (Table 2). However, a late Tournaisian or early Viséan age is also tenable because both these species are known in this interval and furthermore younger characteristic species might be hidden in opaque specimens. This is however unprobable because of the dominance of the Spelaeotriletes div. sp. which is typical of Tournaisian strata (unless most of the material of course have been recycled).

\section{Reevaluation of Stapleton's results}

Many new species and detailed zonations have appeared since Stapleton's analyses were published in 1977. A reevaluation of his work is therefore necessary, but could be based here only on the examination of the illustrations he provided (Stapleton, 1977b). Some determinations given by this author are too poorly documented to be credible: as, for example, the so-called Ancyrospora ancyrea var. spinobaculata (Pl. V, Figure 1). Others cannot be ascertained only on SEM pictures: for instance, Geminospora antaxios (Pl. IV, Figure 3) cannot be separated from Spelaeotriletes div. sp. if the degree of cavitation of the central body is not observable. The same is true for Verruciretusispora pallida (Pl. II, Figure 2) and Contagisporites optivus var. vorobjevensis (Pl. III, Figure 5). Names of Lower Carboniferous miospores can be given alternatively to those proposed: Leiotriletes ornatus Ischenko 1956 instead of Leiotriletes pyramidalis (P1. I, Figure 1); Cristatisporites indolatus Playford \& Satterthwait 1988 instead of Dibolisporites echinaceus (Pl. I, Figure 4); Grumosisporites ruginosus Playford 1978 instead of Convolutispora sp. (Pl. II, Figure 4). Verrucosisporites pulvinatus (Pl. I, Figure 6) seems to have the exoexine expanded into a series of lobate outgrowths as in the Lower Carboniferous genus Secarisporites Neves 1961.

Eventually the statement by Stapleton $(1977$, p. 428) that "Specimens are much smaller than is usual for Devonian spores. Most of the identified species were only one third to one half of the size indicated in size descriptions" is easily accounted for if the described assemblage is of Lower Carboniferous age. Although typical Devonian species exist in this assemblage (i.e. Hystrichospores like the specimen that we have illustrated in Plate 1, Figure 11 ), it is difficult to verify their quantitative proportion. They represent recycled material. 

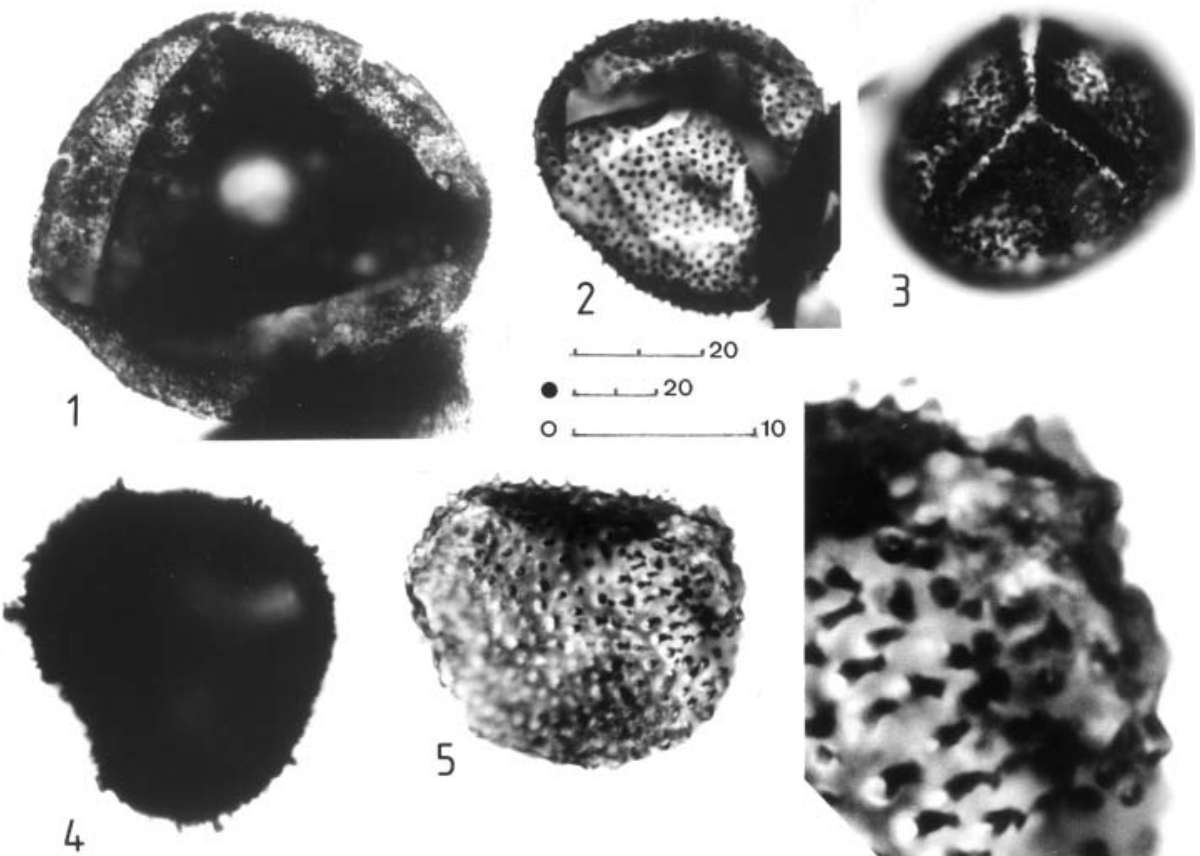

○.

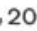
$\perp 10$
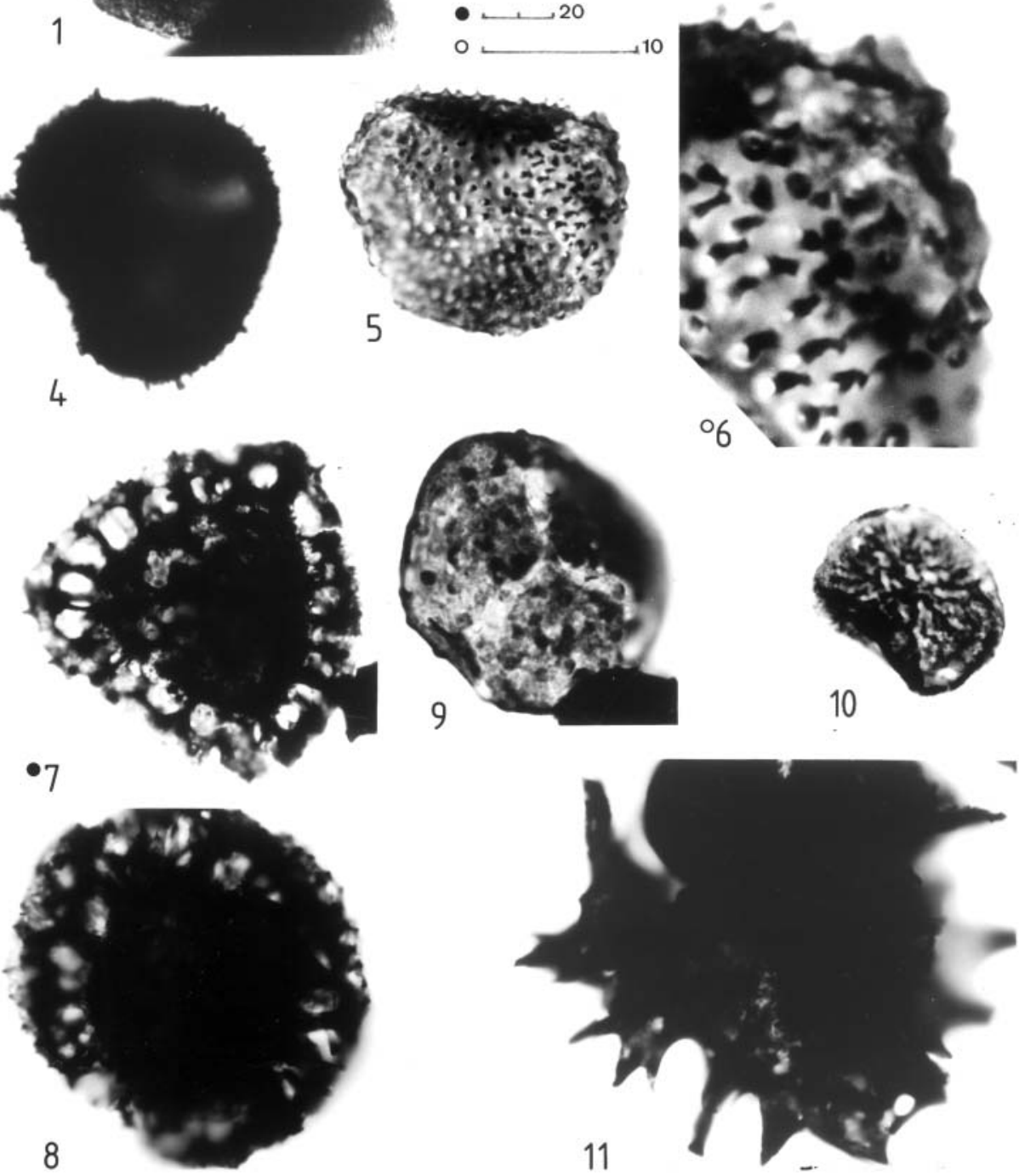

Protolepidodendron by Frenguelli (1954), Drepanophycus by Menendez (1965), Eleutherophyllum? by Cuerda et al. (1968), Lepidodendropsis by Sessarego \& Césari (1989) or Frenguellia by Arrondo et al. (1991). Of more interest for the purpose of the present paper is the opinion of Cuerda et al. (1968) who, based on the evolutionary level of the flora originally described by Frenguelli, suggested an Early Carboniferous age instead of a Middle Devonian age. Later, the rock sequence studied by Frenguelli was incorporated into the Maliman Formation which contains a Lower Carboniferous goniatitid fauna referred to Protocanites. Moreover, since the first discovery made by Frenguelli, $P$. eximium have been found in many localities believed to be of Lower Carboniferous age in South America (Sessarego \& Césari, 1989) where it characterizes the biozone AL (Archaeosigillaria-Lepidodendropsis). Therefore, the material described by Plumstead (1967) from the Waaipoort Formation is no longer confirmation of a Devonian age for this formation.
Plate 1

England Finder grid. gium.

Magnification: see scale bars in $\mu \mathrm{m}$.

\section{slide 34405, grid F42}

slide 34407, grid M49/1

3. Spelaeotriletes balteatus (Playford)

Schopfites cf. delicatus Higgs 1988 , grid F36

\& Jansonius 1964 ,

7. slide 34401 , grid M38/2

8. slide 34401 , grid T53 $\mathrm{T} 42 / 2$

10. Rugospora polyptycha Neves \& Ioan1. Hystrichospore, slide 34401, grid $\mathrm{P} 44 / 4$
Legend of Plate 1

Slides are stored in the Palynological Lab-

slide 34401, grid N53/2

Neves \& Belt 1970, slide 34407, grid ously, whether the African material may be assigned to the South American species, can only be determined by a revision of the actual specimens described by Plumstead, a work well beyond the scope of the present paper. It is additionally not intended to discuss here the successive assignments of the South American species to the genera 


\section{Age of the Waaipoort Formation and its bearing on the position of the Devonian- Carboniferous boundary and the start of the Dwyka glaciation}

In conclusion, the miospores, fish fauna and megaflora (if the plant fossils described from South Africa and South America are conspecific) now concur to assign a Lower Carboniferous age to the Waaipoort Formation. This age is not older than the Middle Tournaisian, thus supporting the suggestion that the Devonian-Carboniferous boundary in South Africa lies at the level of the conspicuous lithological reversal represented by the Witpoort/Kweekvlei contact. In the southern part of the basin the degree of glacial erosion of the uppermost Witteberg units was on a small scale and localized. Of major significance in this regard are dropstones in the uppermost Witteberg beds as well as soft sediment deformational features ascribed to glacial action, sporadic variable erosional features from different localities and the presence of a limited amount of debris of Cape Supergroup derivation in the basal tillite towards the north. Futhermore, northwards older (i.e., stratigraphycally lower), Witteberg units are gradually exposed immediately beneath the abovementioned glacigene surface. All the evidence displayed indicates overriding of the glaciers relatively shortly after deposition of the uppermost Witteberg sediments.

\section{Acknowledgements}

We would like to thank Sergio Archangelsky who provided information on the South American megaflora as well as Kenneth Higgs and Stanislas Loboziak for helping the miospore identification.

\section{References}

Anderson, J. and Anderson H.M., 1985, Paleoflora of Southern Africa: Prodromus of Southern African Megafloras, Devonian to Lower Cretaceous: AA Balkema, Rotterdam, pp. 1-423.

Anderson, H.M., Hiller, N. and Gess, R.W., 1995, Archaeopteris (Progymnospermopsida) from the Devonian of southern Africa: Botanical Journal of the Linnean Society, v. 117, pp. 305-320.

Arrondo, O., Césari, S.N. and Guttierez, P.R., 1991, Frenguellia, a new genus of lycopods from the Early Carboniferous of Argentina: Review of Palaeobotany and Palynology, v. 70, pp. 187-197.

Boucot, A.J., Brunton, C.H.C. and Theron, J.N., 1983, Implications for the age of South African Devonian rocks in which Trilepidoleptus (Brachiopoda) has been found: Geological Magazine, v. 120, pp. 51-58.

Braman, D.R. and Hills, L.V., 1992, Upper Devonian and Lower Carboniferous miospores, western district of Mackenzie and Yukon Territory, Canada: Palaeontographica Canadiana, $n^{\circ} 8$, pp. 1-97.

Cooper, M.R., 1986, Facies shifts, sea-level changes and event stratigraphy in the Devonian of South Africa: South African Journal of Science, v. 82, pp. 255-258.

Cuerda, A., Wagner, R. and Arrondo, O., 1968, Observaciones sobre algunas floras del Carbonifero argentino: Ameghiniana, v. 5, $\mathrm{n}^{\circ}$ 7, pp. 265-269.

Daemon, R.F., 1974, Palinomorfos-Guias do Devoniano Superior e Carbonifero Inferior das Bacias do Amazonas e Parnaiba: An. Acad. brazil. Ciênc. v. $46 n^{\circ}$ 3/4, pp. 549-587.

Frenguelli, J., 1954, Plantas devonicas de la Quebrada de la Charnela, en la Precordillera de San Juan: Notas Fac. Cs. Nat. Mus. La Plata, v. 18(102), pp. 359-376.

Gardiner, B.G., 1969, New Palaeoniscoid fish from the Witteberg Series of South Africa: Zoological Journal of the Linnean Society,v.48, pp. 423452.

Higgs, K., Clayton, G. and Keegan, J.B., 1988, Stratigraphic and systematic palynology of the Tournaisian rocks of Ireland: The Geological Survey of Ireland, Special paper $\mathrm{n}^{\circ}$ 7, pp. 1-93.

Higgs, K., Dreesen, R., Dusar, M. and Streel, M., 1992, Palynostratigraphy of the Tournaisian (Hastarian) rocks in the Namur Synclinorium, West Flan- ders, Belgium: Review of Palaeobotany and Palynology, v. 72, pp. 149158.

Hiller, N. and Theron, J.N., 1988, Benthic communities in the South African Devonian, in McMillan, N.J., Embrey, A.F. and Glass, D.J., eds, Devonian of the world, v. III, palaeontology, palaeoecology and biostratigraphy: Mem. 14, Canadian Society Petroleum Geologists, pp. 229-242.

Lanzoni, E. and Magloire, L., 1969, Associations palynologiques et leurs applications stratigraphiques dans le Dévonien supérieur et Carbonifère inférieur du Grand Erg occidental (Sahara algérien): Revue de l'Institut français du Pétrole, v. 24 n 4 , pp. 441-469.

Menéndez, C., 1965, Drepanophycus eximius (Frenguelli) nov. comb. del Devonico de la Quebrada de Chavela, San Juan: Ameghiniana, v. 4, n ${ }^{\circ} 4$, pp. 139-140.

Plumstead, E.P., 1967, A general review of the Devonian plants found in the Cape System of South Africa: Palaeontologica Africana, v. 10, pp. 1-83.

Sessarego, H.L. and Césari, S.N., 1989, An Early Carboniferous flora from Argentina. Biostratigraphic implications: Review of Palaeobotany and Palynology, v. 57, pp. 247-264.

Stapleton, R.P., 1977a, Carboniferous unconformity in southern Africa: Nature, v. 268, pp. 222-223.

Stapleton, R.P., 1977b, Carbonized Devonian Spores from South Africa: Pollen et Spores, v. $19, \mathrm{n}^{\circ} 3$, pp.427-440.

Taylor, F.F. and Hiller, N., 1992, New Devonian plant macrofossils from the Witteberg Group near Grahamstown (abs): 7th biennal conf., Palaeontological Society South Africa, p. 41.

Theron, J.N., 1994, The Devonian-Carboniferous Boundary in South Africa: Annales de la Société géologique de Belgique, T. 116, n 2, pp.291-300.

Theron, J.N. and Johnson, M.R., 1991, Bokkeveld Group (including the Ceres, Bidouw and Traka Subgroups), in Johnson M.R., ed, SACS Catalogue of South African Lithostratigraphic Units, 3, pp. 3-5.

Young, G.C., 1989, The Aztec fish fauna (Devonian) of Southern Victoria Land: Evolutionnary and biogeographic significance, in Crame J.A., ed, Origins and evolution of the Antarctic biota, London: Geological Society Special Publication, ${ }^{\circ} 47$, pp. 43-62.

Dr. Maurice Streel received his doctoral degree at the University of Liège for research on the phytosociology of savannahs from central Africa. Later on he was Assistant and then Professor in the Paleobotany Department of the same university where he introduced palynology lectures and researches. He is Honorary Professor since 1995. He was Secretary of the IUGS Working Group on the Devonian-Carboniferous Boundary. His research concentrates on the Devonian and Carboniferous miospores.

Dr. Johannes $N$. Theron received his doctoral degree at the University of Stellenbosch. During his career of 34 years at the Geological Survey of South Africa, tasks covered most of the fields of geology, focussing mainly on regional mapping in the South Western Cape. Head of the regional GSO office in the Cape from 1972 to 1988. Senior Specialist Scientist until retirement in 1994. Main research interest is the Lower Paleozoic sedimentary sequences in the Cape Province. Corresponding Member for South Africa of the Subcommissions on Ordovician and Devonian Stratigraphy of the IUGS since 1987.
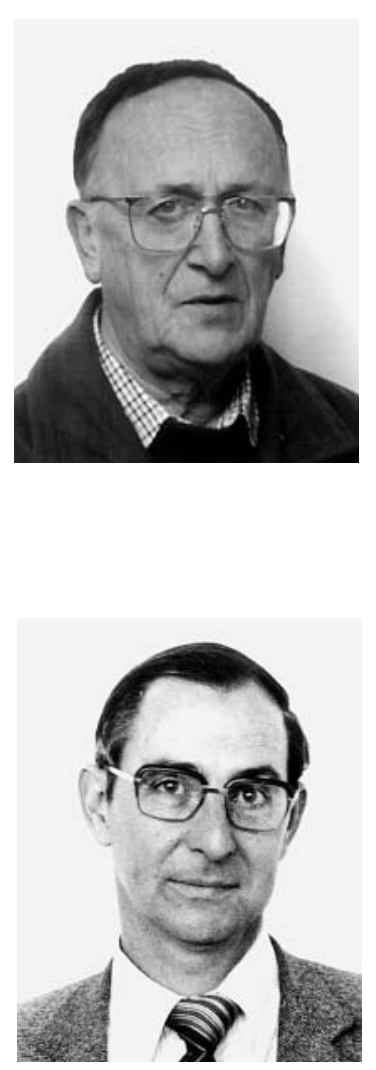